\title{
Successful rehabilitation of a sand dune system
}

\author{
J. S. Antunes do Carmo ${ }^{1}$, C. S. Reis ${ }^{2}$, \& H. Freitas ${ }^{2}$ \\ ${ }^{1} I M A R$, Institute of Marine Research, Department of Civil Engineering, \\ Coimbra University, Coimbra, Portugal \\ ${ }^{2} I M A R$, Institute of Marine Research, Department of Botany, \\ Coimbra University, Coimbra, Portugal
}

\begin{abstract}
The construction of an underwater effluent damaged the continuity of the Leirosa sand dune system, which is located at south of Figueira da Foz, midway along the Portuguese coast. The use of heavy machinery in this fragile area has worsened the erosive effect already caused by an existing groyne one kilometre north of the affected area. The recovery of this system started in 2000, with the artificial reconstruction of the dunes followed by replanting. In February 2001, however, during a storm whose impact was felt all over the central area of Portugal, and especially on the coast, the oceanic front of the Leirosa dune system was destroyed, and alternative hard protection devices have been encouraged. The study carried out showed that a submerged breakwater could be an interesting and efficient strategy, not only to protect the coastal system, but also to increase recreational beach activities. However, the costs involved and the time required to implement this solution have been considered insupportable and, as a consequence, the local industries involved decided on another solution. Geotextiles have been successfully used in hydraulic engineering and more recently also in the construction of artificial dunes and stabilisation of beach nourishment measurements. It is shown that the use of geotextiles can be as effective as any so called "hard engineering protection", with the advantage of being adaptable to the morphology of the dune system and using locally available sand.
\end{abstract}

Keywords: sand dunes, coastal protection, submerged breakwaters, geotextiles. 


\section{Introduction}

In general, the coasts are nowadays hugely popular places to go for holidays or a day out. Residents and visitors alike are attracted by the sandy beaches, striking scenery and the chance to 'get away from it all'. They provide limitless scope to watch wildlife, pursue outdoor sports such as diving and sailing, or simply walk, contemplate and seek inspiration.

Unfortunately, massive tourist use of many beaches has been followed by the destruction of many coastal dune areas in recent decades all over the world. Reconstruction of destroyed dunes is nearly impossible because many of these zones have been taken over by resorts, or in some other cases, the new dunes are smaller and more linear than the natural dunes they have replaced.

It is to everyone's benefit to maintain the qualities that make the coasts such special places - their beauty, diversity and wildness. Visitor pressure alone can severely damage the natural environment of these coasts. Too much trampling encourages dune erosion. Beaches may be spoilt by litter and sewage. In general, coastlines are fragile environments and we need to be aware of the impact our own activities may have. This is vital if we are to conserve the quality of our coastlines and ensure that they can be enjoyed by many generations to come.

In many coastal zones, it is not uncommon for sand or shingle to be taken from beaches or dunes. This may be used for anything from building to the filling of bunkers on golf courses or, where beach sands are particularly shelly and lime rich, for use on farmland. Where this is done by local landowners or smallholders for their own use, there is usually little impact; however, where sand and shingle is removed commercially, this can have a dramatic impact on the appearance and natural heritage of the coastline.

The removal of sand or gravel can also have a major impact on the stability of the coastline. Little fresh sediment is being fed to the coastline today from natural sources. So, when sand or shingle is taken from a beach, it is not replaced from off-shore. Instead, the pit created is simply filled in from the surrounding beach. As a result beach levels fall, increasing erosion of the dunes or land behind.

Apart from housing and industry, the coastlines of the most heavily developed areas, normally those around big cities, support ports and harbours, power stations, roads and railways, defence establishments and, of course, scores of golf courses and other recreational and tourist facilities.

In these areas, particularly, there is constant pressure for further development, linked with industry, housing or leisure. If uncontrolled, such development can gradually eat away at the character and natural heritage of the coast. Planning policies need to be sensitive to the potential damage which can be caused to natural habitats and landscapes by inappropriate or piecemeal development along the coast. If a coastal location is not essential then a new development should be directed away from the shoreline; however, if a coastal location is essential, it should be accommodated within already developed coastal areas.

Where building takes place on shifting coastlines, there is usually pressure to protect the land from erosion. Yet coastal defences can create problems of their 
own, by obscuring natural habitats on the shoreline, for instance. By interfering with the supply or movement of beach sediment, some defences can even increase erosion on unprotected shores nearby.

Defences are also expensive and need regular maintenance to remain effective. For these reasons, new development on such coastlines is generally inappropriate unless the location is essential to the scheme's viability. Where new defences are considered vital to protect existing development, there is a clear need to consider the wider environmental effects, particularly on coastal evolution. Greater knowledge about how sediment moves around our coastline will help us predict where such impacts might occur and create coastal defence proposals to suit each location.

In the long run, it may prove even cheaper and less environmentally damaging to move existing buildings or facilities further inland if they are threatened by coastal erosion. With current forecasts of rising sea levels and likelihood of increased storms due to global warming this is an option that may become increasingly likely in the future.

\section{The case of Leirosa sand dune system}

The Leirosa sand dunes are located to the south of Figueira da Foz, midway along the Portuguese coast. The construction of the underwater effluent emissary of the Stora Enso (Celbi) and Soporcel factories damaged the continuity of this sand dune system. The use of heavy machinery in this fragile area aggravated the erosion already caused by a breakwater one kilometre north of the affected area. The recovery of the Leirosa system started in 2000, with the artificial reconstruction of the dunes followed by the replanting of the foredune with Ammophila arenaria. This beach grass is widely used all over the European coast in the rehabilitation of degraded systems due to its unique capacity for sand stabilization and dune formation (Reis and Freitas [1]).

A monthly monitoring plan was set up to see how the rehabilitated sand dune developed. After only a few months, several dune species started to colonize the area, meaning that the system was beginning to stabilize. However, in February 2001, during a storm that struck all of central Portugal, especially the coast, the oceanic front of the Leirosa dune system was destroyed. After this breakdown, the monitoring plan was kept up on in the continental side of the dune, and the results were rewarding since in only a little more than a year a stable dune was formed, with the colonization of about 25 plant species and a significant increase of the percentage of plant cover (Reis and Freitas [1]). The situation on the ocean side was different, however, since after the storm, and with the loss of all the plant cover and a considerable amount of sand, the erosion was intensified on this part of the dune, as shown in Figure 1.

As a consequence, alternative hard protection devices have been encouraged. A protection of this type can be both complementary to the rehabilitation with vegetation and, at the same time, a long-term robust protection.

Next we describe some of the studies undertaken to design a submerged breakwater under high tide conditions. 


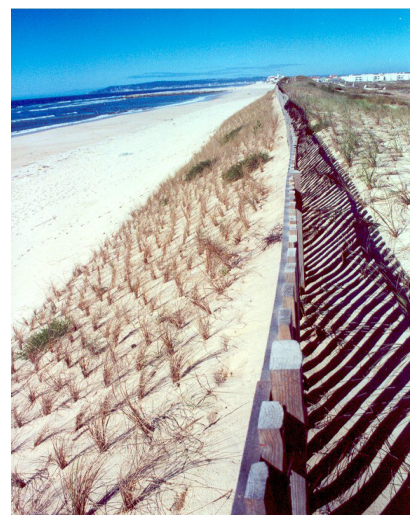

a) May 2000

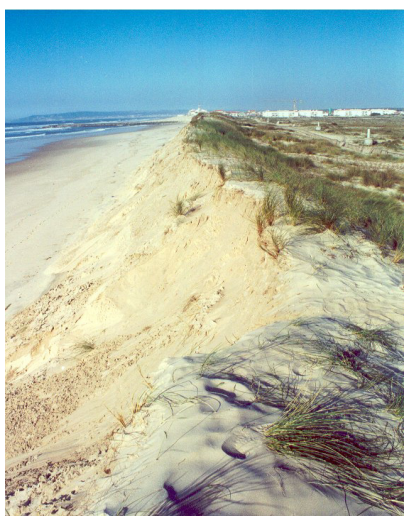

b) February 2001

Figure 1: Reconstructed sand dune system, in May 2000, and its destruction due to a winter storm in early 2001 (Antunes do Carmo [2]).

\subsection{Hydrodynamic studies}

With the intention of constructing an efficient hard structure to dissipate wave energy, and so to protect the sand dune from more energetic conditions, the following typical situations were considered and tested (after various statistical studies based on observations and other information obtained by the Portuguese Hydrographic Institute and by the ex-Autonomous Board of Figueira da Foz port - Seabra-Santos et al. [3]; StoraEnso [4]) (Antunes do Carmo, 2003 [2]):

1. High-tide $3.60 \mathrm{~m}(\mathrm{ZH})$; significant wave height $\mathrm{H}_{\mathrm{s}}=2.5 \mathrm{~m}$; period $\mathrm{T}=7.0$ sec.

2. High-tide $3.60 \mathrm{~m}(\mathrm{ZH})$; significant wave height $\mathrm{H}_{\mathrm{s}}=2.5 \mathrm{~m}$; period $\mathrm{T}=10.0 \mathrm{sec}$.

3. High-tide $3.80 \mathrm{~m}(\mathrm{ZH})$; significant wave height $\mathrm{H}_{\mathrm{s}}=5.0 \mathrm{~m}$; period $\mathrm{T}=13.0 \mathrm{sec}$.

4. High-tide $3.80 \mathrm{~m}(\mathrm{ZH})$; significant wave height $\mathrm{H}_{\mathrm{s}}=6.0 \mathrm{~m}$; period $\mathrm{T}=15.0 \mathrm{sec}$.

5. High-tide $3.80 \mathrm{~m}(\mathrm{ZH})$; significant wave height $\mathrm{H}_{\mathrm{s}}=7.0 \mathrm{~m}$; period $\mathrm{T}=17.0 \mathrm{sec}$.

6. High-tide $4.00 \mathrm{~m}(\mathrm{ZH})$; significant wave height $\mathrm{H}_{\mathrm{s}}=7.0 \mathrm{~m}$; period $\mathrm{T}=17.0 \mathrm{sec}$.

These sinusoidal wave characteristics were considered as input boundary conditions for a suitable numerical model, based on Boussinesq type equations (Antunes do Carmo et al. [5]; Antunes do Carmo and Seabra-Santos [6]), at a distance of $1450 \mathrm{~m}$ from the existing sand dune base, and in a region where the water column is about $14.5 \mathrm{~m}$ deep. The results for conditions 2,5 and 6 are 
presented in detail in Reis et al. [7]. These conditions represent characteristic situations of calms and storms over an installed submerged breakwater, followed by a platform (see Figure 2), and with the crest level situated $2.0 \mathrm{~m}$ above the zero hydrographic level $(\mathrm{ZH})$.

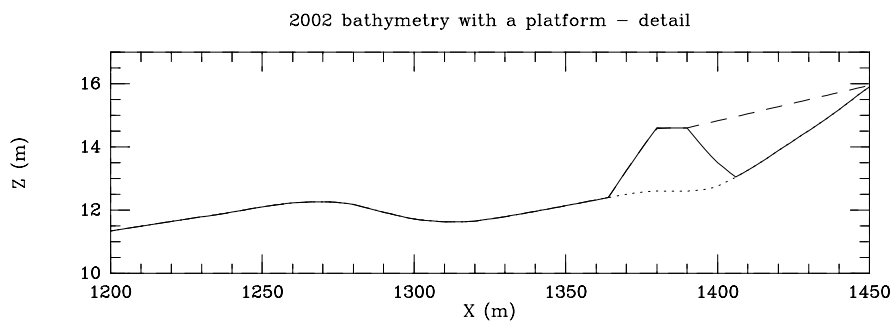

Figure 2: Detail of the bathymetry with a platform installed (continuous line) 60-70 $\mathrm{m}$ before the existing sand dune base (Reis et al. [7]).

As shown in Reis et al. [7], all these situations lead to a significant reduction of wave amplitude and also, as a consequence, its energy potential, after the generalized wave breaking process over the platform, approximately $60 \mathrm{~m}$ to $70 \mathrm{~m}$ away from the sand dune base and a $2.0 \%$ to $2.5 \%$ slope.

That study therefore showed that a submerged breakwater could be an interesting and efficient strategy, not only to protect the coastal system, but also to improve the bathing conditions of a large coastal zone.

The reduction of the wave energy, and its effect on the hydrodynamics regime and the sediment transport should however be studied in a greater detail, as these phenomena are extremely important and complex. In addition, the costs involved and the time required to implement this solution have been considered insupportable and, as a consequence, the industries involved decided on another solution, which is described in detail in Reis et al. [7].

All around the world, sand-filled geosynthetic containers are playing a bigger and bigger role in the construction of coastal and marine structures. Traditional construction techniques using rock, concrete and steel are being increasingly challenged by alternatives offered in geosynthetic forms for revetments, scour protection, groynes, berms, artificial reefs, reclamation and dune stabilization, to name but a few uses. Furthermore, improvements in materials, design and construction methods for such structures are enhancing and diversifying the range of possibilities and applications.

The solution implemented to stabilize the Leirosa sand dune system consisted of placing geotextile containers filled with sand. Figure 3 illustrates the technique and placement of the sand containers in layers. Once the sand containers were in place, this protection "barrier" was covered by a $1.0 \mathrm{~m}$ layer of sand which was planted with dune vegetation, turning this area into an attractive and safe coastal dune system. This technique, in particular the design and the different construction phases, which were completed between April and June 2005, are also explained in detail in Reis et al. [7]. 
Figure 4 shows two different configurations of the intervention: a) Dune system state before winter (September 2005), and b) Present configuration (February 2006).

About seven months after the reconstruction of the Leirosa sand dune system, we can now present the different phases of the implemented monitoring plan.

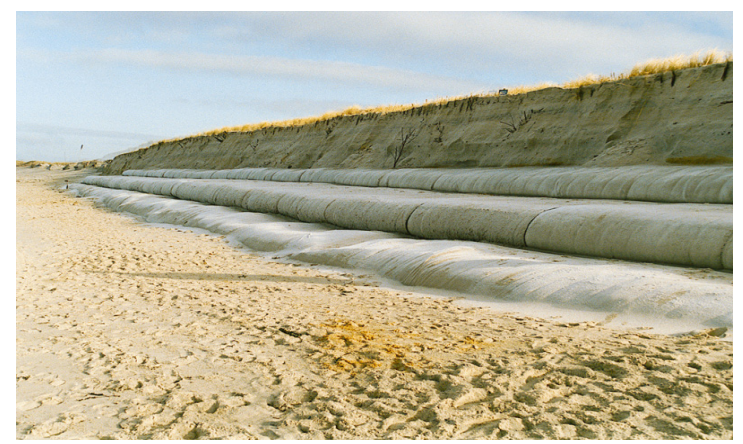

Figure 3: Application of geotextiles in coastal protection.

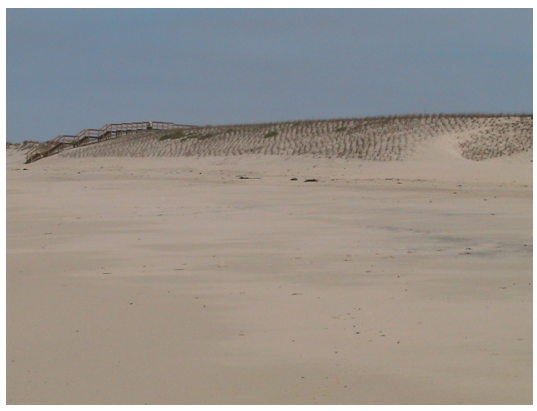

a) September 2005 (before winter).

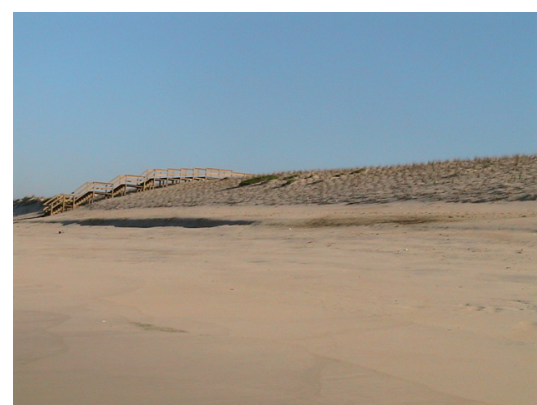

b) February 2006.

Figure 4: Leirosa sand dune system: two different states of the intervention area.

\subsection{Monitoring plan}

A monitoring plan was set up and implemented immediately after the replanting work. The entire restored dune was considered, with particular attention to the replanted areas. The emergence of new species was noted and sand mobility was evaluated by means of the small, graduated, wooden posts that were distributed throughout the rehabilitated system.

\subsubsection{Characterization of the restored dune}

About 8225 culms of Ammophila arenaria were transplanted in a tight pattern of $50 \mathrm{~cm}$ in a diagonal grid. Although all plants were alive at the time of transplantation, due to the stress during replanting and also because of the high 
temperatures, all plants were apparently dry after one month. However they were not dead, as could be confirmed by looking more closely at the underground system, where new roots were forming. For this reason no parameters related to the growth or flowering of the plants were taken into consideration in the first six months of the monitoring work.

The restored dune was delimited by a previous dune system where some other plants were growing. Their location and classification were also recorded in the first month of the monitoring work. In addition to Ammophila arenaria ten other dune plant species were identified: Calystegia soldanella, Crucianella maritime, Pancratium maritimum, Elymus farctus, Artemisia maritime, Medicago marina, Silene littorea, Eryngium maritimum and Euphorbia paralias.

\subsubsection{Vegetation monitoring}

A small amount of a slow release fertilizer was used during planting to allow a better stabilization of the transplants. But it also contributed to the appearance of certain plants like Cakile maritime which is thriving on the ocean side of the restored dune. This was the first plant species to colonize the area replanted exclusively with Ammophila arenaria transplants.

The identification and localization of all plant species that colonized the restored dune are given in the following table.

Table 1: Identification of all plant species that colonized the restored dune.

\begin{tabular}{|c|c|c|c|c|c|}
\hline Area 1 & Area 2 & Area 3 & Area 4 & Area 5 & Area 6 \\
\hline- & $\begin{array}{c}\text { Artemisia } \\
\text { maritima }\end{array}$ & - & - & - & $\begin{array}{c}\text { Artemisia } \\
\text { maritime }\end{array}$ \\
\hline $\begin{array}{c}\text { Cakile } \\
\text { maritime }\end{array}$ & $\begin{array}{c}\text { Cakile } \\
\text { maritime }\end{array}$ & $\begin{array}{c}\text { Cakile } \\
\text { maritime }\end{array}$ & $\begin{array}{c}\text { Cakile } \\
\text { maritime }\end{array}$ & $\begin{array}{c}\text { Cakile } \\
\text { maritime }\end{array}$ & $\begin{array}{c}\text { Cakile } \\
\text { maritime }\end{array}$ \\
\hline $\begin{array}{c}\text { Calystegia } \\
\text { soldanella }\end{array}$ & $\begin{array}{c}\text { Calystegia } \\
\text { soldanella }\end{array}$ & $\begin{array}{c}\text { Calystegia } \\
\text { soldanella }\end{array}$ & $\begin{array}{c}\text { Calystegia } \\
\text { soldanella }\end{array}$ & $\begin{array}{c}\text { Calystegia } \\
\text { soldanella }\end{array}$ & $\begin{array}{c}\text { Calystegia } \\
\text { soldanella }\end{array}$ \\
\hline $\begin{array}{c}\text { Elymus } \\
\text { farctus }\end{array}$ & $\begin{array}{c}\text { Elymus } \\
\text { farctus }\end{array}$ & - & $\begin{array}{c}\text { Elymus } \\
\text { farctus }\end{array}$ & - & Elymus farctus \\
\hline $\begin{array}{c}\text { Eryngium } \\
\text { maritimum }\end{array}$ & $\begin{array}{c}\text { Eryngium } \\
\text { maritimum }\end{array}$ & $\begin{array}{c}\text { Eryngium } \\
\text { maritimum }\end{array}$ & $\begin{array}{c}\text { Eryngium } \\
\text { maritimum }\end{array}$ & $\begin{array}{c}\text { Eryngium } \\
\text { maritimum }\end{array}$ & $\begin{array}{c}\text { Eryngium } \\
\text { maritimum }\end{array}$ \\
\hline $\begin{array}{c}\text { Euphorbia } \\
\text { paralias }\end{array}$ & $\begin{array}{c}\text { Euphorbia } \\
\text { paralias }\end{array}$ & $\begin{array}{c}\text { Euphorbia } \\
\text { paralias }\end{array}$ & $\begin{array}{c}\text { Euphorbia } \\
\text { paralias }\end{array}$ & $\begin{array}{c}\text { Euphorbia } \\
\text { paralias }\end{array}$ & $\begin{array}{c}\text { Euphorbia } \\
\text { paralias }\end{array}$ \\
\hline- & - & - & - & - & $\begin{array}{c}\text { Euphorbia } \\
\text { peplis }\end{array}$ \\
\hline- & - & - & - & $\begin{array}{c}\text { Medicago } \\
\text { marina }\end{array}$ \\
\hline- & - & - & $\begin{array}{c}\text { Polygunum } \\
\text { maritimum }\end{array}$ & $\begin{array}{c}\text { Polygunum } \\
\text { maritimum }\end{array}$ & $\begin{array}{c}\text { Polygunum } \\
\text { maritimum }\end{array}$ \\
\hline
\end{tabular}

The six areas correspond to the areas between the eight transects marked out by the graduated posts for the sand mobility monitoring (next section). It can be seen that in only six months eleven plant species colonized an area where only Ammophila arenaria was planted. Four of those species occur in all six defined 
areas. The southern area, the most protected from the winds, is where the highest number of plants and a greater diversity of species were found.

\subsubsection{Sand mobility}

The monitoring of the sand mobility was another important aspect that was covered in this study. For this, 24 graduated wooden posts were distributed along the restored dune system. Eight transects, about $15 \mathrm{~m}$ apart and perpendicular to the coastline were delineated. Three graduated wooden posts were placed in the sand, in each transect: the first one on the top of the dune, on the landward side; the second one on the top of the dune towards the ocean side, and the third one at the base of the ocean side (Figure 5).

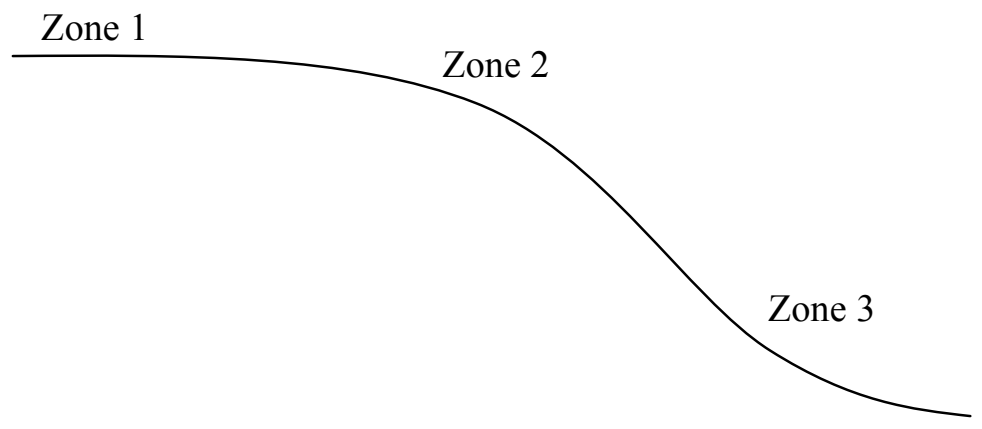

Figure 5: The sand mobility posts' distribution.

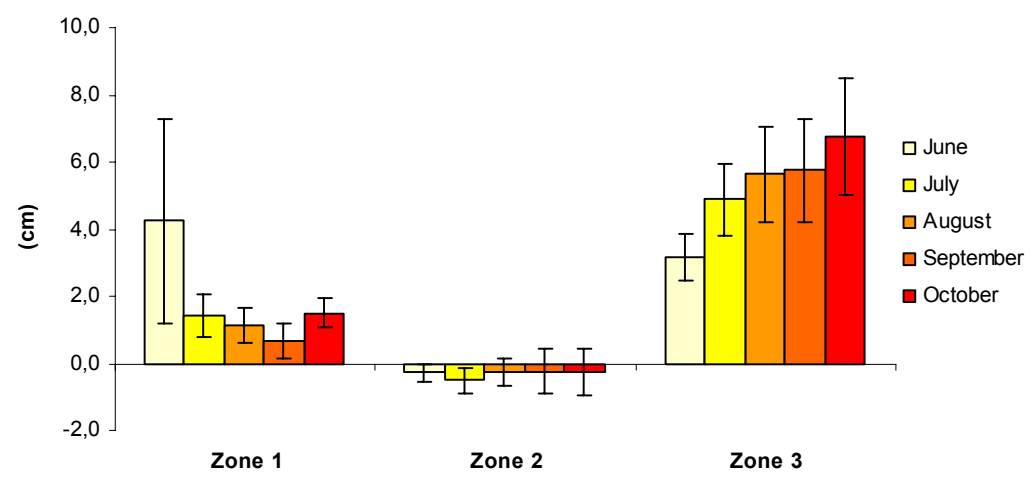

Figure 6: Sand mobility measured by the graduated posts placed along the restored dune system (Mean $\pm \mathrm{SE})$. 
All posts were placed at zero level in the first month of the monitoring work, and every month the sand mobility was measured (Figure 6). After six months there is a clear distinction between the three defined zones.

A pronounced reduction on the sand level of the zone 1 was registered between June and September, which might explain the loss of two posts from this zone, one of them probably due to the enormous amount of sand that accumulated on the extreme north side of the dune.

Zone 2 is the only one where some erosion was noticed, although in a very small quantity and very stable over the period. Constant sand accumulation was registered over the six month monitoring period in zone 3 , where the highest values of sand accretion were also registered.

This is important since zone 3 corresponds to the base of the restored dune closer to the beach area, which works as the first defense in a storm.

\section{Conclusions}

The construction of an underwater effluent damaged the continuity of the Leirosa sand dune system, which is located midway along the Portuguese coast. To protect this fragile ecosystem, a barrier of sand containers was constructed, and a top layer of sand was replanted with beach grass, turning this area in an attractive and safe coastal dune system. The solution implemented to stabilize this sand dune system consisted of constructing sand containers enclosed by geotextiles. A monitoring plan was set up and instituted immediately after the replanting work.

It was the first time that procedure described in this paper had been used on the Portuguese coast, specifically in the Leirosa sand dune system, and links the advantage of being complementary to the rehabilitation of the dune with natural vegetation, and can be, at the same time, a long-term robust protection. We believe that the work developed in the Leirosa sand dunes can become an important model to be applied in other dune systems with similar erosion problems.

\section{References}

[1] Reis, C.S. \& Freitas, H., 2002. Rehabilitation of the Leirosa sand dunes. In EuroCoast-Portugal Association (ed.) Littoral 2002, Porto, 22-26 September 2002. Porto, Portugal. III: 381-384.

[2] Antunes do Carmo J.S., 2003. Littoral dynamics and coastal protection: A case study. Proceedings of the "VI SILUSBA", Praia, Cabo Verde, November 10-13.

[3] Seabra-Santos, F.J., Lopes de Almeida, J.P. \& Antunes do Carmo, J.S., 1991. Final Report of the Research Project "Lançamento de Bases para o Estudo Integrado do Estuário do Mondego. Estudo da Agitação Marítima", December.

[4] StoraEnso, 2003. Dune erosion - sent data. Personal documentation offered by StoraEnso, May. 
[5] Antunes do Carmo, J.S., Seabra-Santos, F.J. \& Barthélemy, E., 1993. Surface waves propagation in shallow-water: a finite element model. Int. J. Num. Meth. in Fluids, 16, 6, pp. 447-459.

[6] Antunes do Carmo J.S. \& Seabra Santos, F. J., 1996. On breaking waves and wave-current interaction in shallow water: a $2 \mathrm{DH}$ finite element model. Int. Journal for Num. Meth. in Fluids, Vol. 22, 429-444.

[7] Reis C.S, Freitas H. \& Antunes do Carmo J.S., 2005. Leirosa sand dunes: A case study on coastal prototection. Proc. IMAM - Maritime Transportation and Exploitation of Ocean and Coastal Resources, Lisboa, 26-30 de September, 1469-1474. Ed. Taylor \& Francis/BALKEMA. ISBN Vol. 2: 041539374 4, CD-Rom: 0415394333. 